\title{
JAPAN: ECONOMIC SUCCESS AND LEGAL SYSTEM
}

\author{
Edited by Harald Baum, published de Gruyter, Berlin 1997, pp i-xxii, 1-401 \\ Reviewed by A H Angelo*
}

This book is the record of the 1995 conference on "Japan: Economic Success and Legal System" which was held at the Japanese-German Center, Berlin, Germany. Of the 24 recorded contributors to the conference, the papers of 17 are produced in this volume and the contributions of the other 7 to the conference are noted in the chapter which reports on the closing discussion of the conference.

The conference organisers gathered an impressive list of specialists in the field of Japanese legal studies, including names made famous by many years of publication and also younger scholars and practitioners. The book could very readily be used either as a comparative law textbook or a text on the comparative study of the Japanese legal system. It is an excellent contemporary statement of the relevant law and review also of the current literature and thought.

There is much information that is new in this volume. There are also many thoughts and ideas which, though expressed before, are refined and elaborated in the light of the most recent research. The perennial issues of Japanese legal study, such as those relating to the number of lawyers, the attitude to law, and the role of harmony are not addressed in general terms in the chapters but only specifically in the context of detailed statistical and practical factual information. The issues in their general form appear, from chapter 15, never to have been far below the surface, because in that final session there were what is described as "various intense discussions" (page 373) and there the arguments appear again in their more general form.

All in all the volume is an excellent one and gives cause for reflection both on matters of Japanese law and comparative law, and also on the human condition generally. The interrogation implicit in the title of the book about the relationship between economic sucess and legal system is a challenge both for economists and lawyers. Having read the volume, the answer of this reviewer to the question is yes. The text itself in its concluding

* Professor of Law, Victoria University of Wellington. 
chapters is much more cautious (see pages 391 and 395), but, subject to a great number of qualifications, probably indicates the same conclusion.

The book is in four main parts which group the chapters under the headings of "Lawyers, Mediators, and Legal Culture", "Law and Contract in Japanese Business", "Aspects of the Japanese Enterprise", and "The Bureaucracy in Japanese Economic and Legal Affairs". There is in addition an Introduction and a fifth part which involves the conference discussion notes, and concluding remarks in a final chapter.

The opening chapter is by the editor, Harald Baum. He begins by enquiring whether "a non-litigious people [is] cleverly not wasting scarce resources on lawyers and law suits and still providing for an adequate measure of intra-societal justice?" and ends with the thought that other states should not be emulating Japan but should be learning from it - in particular, the willingness to look beyond national borders for usable solutions to local problems, and the inherent flexibility of its system. The chapter considers the fact that in the late 1980s more than two thirds of commercial contracts made by Japanese companies were concluded only orally (page 16) and also considers (page 17) social attitudes towards law which continue from an agrarian feudal state. It is also the fact that Japanese parties bargain in "the shadow of the law" (page 22). In respect of the possibility of the German model as a middle way between United States and a "right-line society" (page 22) Baum doubts the usefulness of the German model about which he comments: "that of a society where it is legally much easier to get rid of a spouse than of a tenant in a flat, things seem to be a bit out of balance".

The discussion of dispute resolution (which is dealt with also in the chapter by Professor Henderson) gives rise to questions whether it is not just the dispute resolution method that is favoured that is different in Japan from, for instance, the United States or Germany, but perhaps the focus of the dispute resolution process itself. The state clearly emphasises a particular type of dispute resolution, and by so doing indirectly favours the settlement of particular types of disputes by the state process. May it not be the case that Japan gives priority in dispute resolution to the common situation and not to the extreme? In New Zealand and the US it would appear that the state is concerned much more with the extreme or unmanageable dispute. For that purpose it puts in place a dispute resolution method which is objective and independent of the parties. The norm - the everyday dispute - is left to the parties to that dispute to resolve as best they can in their own way. In formal terms, the state really takes no interest in such disputes. Its formalised dispute resolution structures do however encourage a settlement of disputes by the parties themselves by avoidance, by discussion, by negotiation or mediation as they see fit and it does this indirectly by the costs, delays and impersonal nature of the judicial mechanism. It may also be that those systems are less suited to parties who are going to have to cooperate or wish to cooperate in the future. It is very much a rights and wrongs oriented process. 
The Japanese system on the other hand appears to be concerned with the continued cooperation of the parties and a mutual accommodation of them in the dispute resolution process. The differences there appear not to be primarily of process but essentially of the goals of the dispute resolution.

In chapter 1 Professor Henderson speaks again of the disputed questions relating to the role of lawyers in Japan. His paper is a review of the known and an update informed by the latest statistics. The study is of lawyers and quasi-lawyers and is given colour by the statements reported later in the volume at pages 376 and 377. Even, he says (page 31), if the quasi-lawyers are added to the bengoshi "the US would still have over twice as many lawyers per capita as Japan". At page 48 he confirms his view that the main cause for relatively low litigation rates in Japan is "because they have other ways, perhaps better ways, to settle disputes".

The theme is pursued in chapter 2 by Professor Kono who considers the behavioural patterns of large Japanese companies in relation to the settlement of disputes, and also by Professor Wollschläger in chapter 3 which considers the historical trends of civil litigation in Japan, Arizona, Sweden and Germany and seeks to establish the historical reasons for the avoidance of litigation. This, chapter 3, is one of the longest papers in the book (50 odd pages) and presents an interesting study of litigation patterns and their causes in the various countries compared. It also offers, notwithstanding the author's disclaimer of the knowledge of the Japanese language, excellent insights into the Japanese legal system.

At page 94 there is a set of figures on international litigation rates in 1990. The graph includes the figures for New Zealand and, perhaps curiously, for Solomon Islands. The rate there is, not surprisingly, very low (4 civil cases per thousand population) and of the countries represented is equal almost to the figure for Nepal which was 3 cases per thousand. The Solomon Islands civil claims data raises other questions about civil litigation trends given the nature of Solomon Islands and the facts that the courts typically operate in a language other than the maternal language of the litigants ${ }^{1}$, that there are virtually no lawyers, that most people are living in native villages more or less at subsistence level with little movable property about which to dispute, and with even more limited possibility of disputing land issues because close to $100 \%$ of the land in Solomon Islands is held subject to indigenous title. A further aspect of the statistic is that in most cases family matters are dealt with within the family and in accordance with custom, and that the courts to the extent they are represented outside of the urban areas are seen to be dealing with criminal law. What are the civil litigation rates of indigenous peoples? And

1 The official language is English, but in their villages the people speak a multitude of indigenous languages. The lingua franca is Pidgin. 
what do they litigate about? Is there, for instance, any data on the use of courts by the Saami or the New Zealand Maori²?

The Wollschläger chapter uses an interesting expression which is new to the reviewer, that is the dunning procedure. This is a reference to the Japanese tokusoku procedure which facilitates the obtaining of a summary judgment for debt and, failing that, may proceed to ordinary judicial enforcement. It is dealt with by articles $430-443$ of the Code of Civil Procedure. The chapter generally shows the importance of economic causes to the patterns of litigation. It appears that the number of lawyers is not the critical factor, but predictability of court results does affect litigation rates. It is further interesting, in thinking back to the introductory chapter, to note at pages 111-113 that the metropolitan centres in Japan in the 18th century were relatively litigious. The agrarian/urban factor is again taken up through the paper at pages 118, 128 and 134. The linkage between the economy and civil litigation patterns is developed at pages 124-125. With reference to the German experience, Professor Wollschläger says

the business community seems to have profited most from civil justice in the 19th century ... Businessment were politically active in demanding unification and modernisation of the law of civil procedure. "Keine Justiz, kein Kredit" (no civil justice, no credit) was a pertinent observation on the relation of law and economy. Merchants were interested in extending credit in order to raise their sales. They needed speedy justice to enforce claims against customers.

In relation to Arizona the impact of population developments in the context of economic developments is marked. In that state, personal relations are relatively anonymous and "the efficient network of dense social relations, which is essential for private dispute resolution and norm enforcement" is not present. The potential for civil litigation is therefore increased. By way of conclusion, at page 133, it is stated that "the size of the economy seems to emerge as the new dominant factor which determines the demand for civil justice". Nevertheless, "in the foreseeable future, the avoidance of litigation will continue as a distinct development of the Japanese legal culture" (page 134).

In chapter 4, Professor Kitagawa brings his experience to bear on the question of the use and non-use of contracts in Japanese business relations. As he points out (page 148) "forming contracts under Japanese law ... is a relatively simple affair". It is also noted that what appears to be a short and simple Japanese contract is of course supported by the general provisions of the Civil and Commercial Codes. This among other things means that common lawyers should not seek to interpret the Japanese contracts in accordance with

2 See Nottage and Wollschläger "What do Courts do?" [1996] NZLJ 369, 371-372. Something of interest to this particular issue is found in the chapter on relational contracting by John Haley (page 173). 
common law principles. The Civil and Commercial Codes follow the typical civil law approach and provide general rules of conduct in relation to contracts. By way of comparison, though there is a significant body of legislation relating to contracts in New Zealand that legislation is generally not of relevance to the standard contract nor in the nature of terms that would otherwise be included in a formal document. They are rather negative in their purpose and deal with the failed contract rather than the healthy one. The New Zealand statutes in general concern the pathological condition of contracts.

Professor Haley presents a wide ranging consideration of the factors that affect contracting and dispute resolution. He explores these issues further in the context of the results of surveys and interviews conducted in New York, Seattle and Japan.

The most stable business relationships in the United States, it appears from the Seattle interviews, are between insurance agents, accountants, and law firms and their customers. This can be explained by the advantages of their institutional memory of their clients business and needs as well as the personal relationships that are inevitably formed ... Similar considerations may also apply in Japan, but it appears that the list of stable partners must be expanded to include suppliers and dealers (page 177).

The conclusion is that in Japan

the community competes with the state as a source of protection and benefit to its members. The community remains cohesive and thus controlling only so long as it also remains a better source of well-being than the state.

Equally important, those who make the law are themselves subject to the same habits, expectations, and values that are shared broadly throughout the society. To the extent that Japan does indeed have a communitarian orientation, its lawmakers would also tend to construct or redefine legal rules and apply them in ways that conform to this broad cultural orientation (page 183).

The matter is taken further with some personal insights in chapter 6 which deals with law, contract and society in Japan ${ }^{3}$. Guntram Rahn moves forward from the theories of Kawashima, Noda, David, and Zweigert to an acceptance of the theory of cultural individuality with a positive connotation and concludes that "pluralism of attitudes ... as

3 A footnote reference for the manga where the Japanese intellectual property lawyer "falls in love with the inhouse lawyer of her clients American competitor, and in between they discuss basic questions, patents, licenses, and intellectual property protection" would have assisted! This useful and relatively shorter (10 pages) piece suffers slightly, in a volume that is otherwise remarkable for its excellent typographical and linguistic preparation, from what appears to be hurried proof-reading. 
well as their manifold combinations apparent in modern day Japan, offer a wealth of operational possibilities and business relationships. This variety of operation possibilities is, in my opinion, greater than in the West and it has contributed to Japan's economic success".

The antipodean perspective on contract law and practice in Japan is presented by Luke Nottage in a way that knits together and interrelates many of the other issues. It links the thoughts also to his on-going research into the applicability of the Atiyah and Summers comparative law framework to Japanese and New Zealand legal systems ${ }^{4}$.

Part 3 presents three aspects of Japanese enterprise. First of all a piece on Japanese corporate groups, and then in chapter 9 a piece on Japanese shareholders and their rights and behaviours. Further information on shareholding behaviour in Japan appears in the report at page 384. Both the company law pieces are useful and precise in their presentation of current data.

The major chapter in this part is that by Professor Foote in his seminal piece on the reduction of working hours in Japan. This is an integrated piece of legal and political research which provides most interesting insights into Japanese labour practices. An interesting Japanese phenomenon reported on is the sabisu zangyo or service overtime which is reported in 1990 to leave $29 \%$ of workers receiving less overtime pay than they were entitled to. This voluntary unpaid or unreported overtime, though not unique to Japan, is striking because of its extent and pervasiveness. Similarly, Japanese workers have historically taken only $50 \%$ of the paid holiday leave to which they are entitled.

Viewed as a whole, the legislative efforts on working hours follow the classic pattern of seeking to achieve change, not through the coercive force of law, but by using law, and governmental persuasion, to change attitudes. To a large extent, this is the same pattern one finds in the equal employment opportunity area. ... This contrast between efforts on working hours on the one hand, and equal employment opportunity, on the other, may simply mean the former is regarded as less controversial and more amenable to change... Yet it may suggest ... that in the Japanese context reducing working hours is treated as a more serious goal than achieving gender equality. (Page 294)

Chapters 11 and 12 by Professors Kanda and Keehn deal each with specific aspects of the state and the guidance of financial markets. Professor Kanda's point is that in every country bureaucrats act within the relevant environment. Professor Keehn develops this by indicating that the Japanese environment is one of state guided capitalism (page 327) where compromised regulatory agencies are often a basic component in the successful

4 The indicative tables on these comparisons, which were originally set out in (1996) 26 VUWLR 247, appear also on pages 221 and 222 of this volume. 
implementation of strategic economic policy. True regulatory independence could too easily contradict the plans of the leading economic bureaucracies and frustrate their use of flexible and informal regulatory tools. And at page 328 "regulatory agencies ... do not have independence and generally are subservient to the strategies of the economic bureaucracies". Despite the calls for change from outside Japan to this pattern of regulation and for more independence of the regulators, the fact is that the pressures on Japan may be to continue government exercise of strategic control. "When all is said and done, the Japanese economic institutions have consistently produced good economic results".

Christopher Heath in chapter 13 looks at comparative and international aspects of the use of intellectual property principles. He cogently shows the relationship of economic development and legal development and how the use of the principles favours nationalist interests.

The old boy network is frequently noted as a striking system of the Japanese political and business systems. Professor Schaede ${ }^{5}$ deals with the pattern of retired government officials who join the boards of private corporations ${ }^{6}$. The conclusion of her study is that the use of "old boys" in large Japanese firms has, despite popular impression, increased over the last decade. The critical factor she finds in distinguishing this old boy network from that in other countries is "that the Japanese bureaucrats are dependent on a de facto government employment agency for their further post-retirement career (page 368).

The discussion at the end of the conference is reported by Dörte Liebrecht who brings together the main themes and interrelates the various chapters. The comments by the participants also add to the interrelationship of the points made in the individual chapters and raise other pertinent data such as the impact of the jury system in civil cases in America and on punitive damages awards in relation to the use of litigation to resolve disputes (page 377). There is also comment that over the last 30 years Japanese business is increasingly moving to written contracts in contrast to the earlier use of oral contracts but that the dispute resolution patterns have not changed markedly despite the uncertainty of administration suggested by the Schaede analysis. Professor Kanda pointed out that in his view, there was actually more regulatory certainty in Japan than in the West (386).

The issue of ethno-centric or nationalistic viewpoints appears again at page 389 in what is reported as a strongly expressed exchange of views between Professor Kitagawa and Professor Henderson (Professor Henderson having described Japan as a "quasi-state trader") which Professor Kitagawa interpreted as implying that Japan should change everything in accordance with American ideas! 
The two conclusions of the reporter at page 391 are that the informality of the norms and intransparency of administrative processes are detrimental to the economic activities of outsiders be they Japanese or foreign, ie the legal system functions as a non-tariff trade barrier. It was also considered doubtful "whether the legal system with its restriction on individual rights had had any significant positive influence on the economic success of the individual Japanese". The concluding remarks re-emphasise the relationship between law and bureaucracy in Japan in a way which recalls the writing of Van Wolferen ${ }^{7}$.

The final word is that of Dr Rodatz who states "in spite of the admirable Professor Henderson's call ... to strengthen the role of law in Japan ... Japanese law is a barrier only as long as we wish to impose our systems, however well they work in our own countries. In Japan we should adapt to the Japanese system, and train our business people accordingly to look far less to lawyers for remedies"8.

7 The Enigma of Japanese Power (MacMillan, London, 1989).

8 Page 395. 